\title{
Green Dialogues and Digital Collaboration on Nonfiction Children's Literature
}

\author{
Diálogos verdes y colaboración digital en literatura infantil de no \\ ficción
}
Diàlegs verds i col-laboració digital en literatura infantil de no- ficció

Marnie Campagnaro. University of Padova, Italy. marnie.campagnaro@unipd.it https://orcid.org/0000-0003-1732-0716

\author{
Nina Goga. Western Norway University of Applied Sciences, Norway. \\ nina.goga@hvl.no
}

https://orcid.org/0000-0001-5658-5237

\begin{abstract}
Contemporary children's literature has developed a growing interest in the interconnectedness between humans and the environment and in the ongoing exchange and negotiation of ways to be in the world. These new directions in children's literature consequently challenge teachers of children's literature in higher education. The study of contemporary children's literature needs not only to be informed by new theoretical perspectives like ecocriticism, posthumanism and new materialism, but also to revisit, develop and explore the methodological tools and teaching practices necessary to prepare students to address these demanding issues. The aim of the article is to present and discuss the research question: How is it possible to secure scholarly dialogue and practical collaboration in an academic course on nonfiction children's literature and environmental issues? Building on a crossdisciplinary theoretical framework consisting of theory of nonfiction, ecocriticism, dialogic teaching, environmental architecture and place-based teaching, the study reports on a pilot course which took place in the summer of 2020. Due to the pandemic situation the course became digital. Hence the digital challenges and possibilities turned out to be a critical aspect of the planned practical collaboration between students, teachers and students and teachers. The main goal of the course was to help motivate students to engage in and negotiate about nonfiction children's literature and sustainability, to enhance their aesthetic experiences and to foster their environmental consciousness through children's literature. The course was characterized by its alternating blending of lectures and hands-on experiences with theoretical and methodological tools as well as nature or culture specific places.
\end{abstract}

Keywords: Nonfiction children's literature, ecocritical dialogue, environmental architecture, digital collaboration, interconnectedness 


\section{Resumen}

La literatura infantil contemporánea ha desarrollado un interés creciente en la interconexión entre los seres humanos y el medio ambiente y en los intercambios y negociaciones en curso sobre las maneras que hay de estar en el mundo. Estas nuevas direcciones en la literatura infantil, consecuentemente, retan al profesorado de literatura infantil en la educación superior. El estudio de la literatura infantil no solo necesita estar al día sobre las nuevas perspectivas teóricas como la ecocrítica, el posthumanismo y el nuevo materialismo, sino también revisitar, desarrollar y explorar las herramientas metodológicas y las prácticas docentes necesarias para preparar el alumnado para abordar estas exigentes problemáticas. El propósito de este artículo es presentar y discutir la pregunta de investigación: ¿Cómo es posible asegurar el diálogo académico y la colaboración práctica en un curso escolar de literatura infantil de no ficción y cuestiones medioambientales? Construyendo un marco teórico interdisciplinar que consistía en teoría de la no ficción, la ecocrítica, la enseñanza dialógica, la arquitectura medioambiental y la educación basada en el lugar, el estudio expone un curso piloto que tuvo lugar en verano de 2020. Debido a la situación pandémica, el curso se convirtió en digital. Así pues, los retos digitales y las posibilidades acabaron resultando un aspecto crítico de la colaboración práctica planificada entre estudiantes, docentes y estudiantes y docentes. El principal objetivo del curso era ayudar a motivar el alumnado para captar su atención y negociar acerca de la literatura infantil de no ficción y la sostenibilidad, mejorar sus experiencias estéticas y nutrir su conciencia medioambiental a través de la literatura infantil. El curso se caracterizó por la alternancia de clases y experiencias prácticas con herramientas teóricas y metodológicas como también con localizaciones culturales y naturales específicas.

Palabras clave: literatura infantil de no ficción, diálogo ecocrítico, arquitectura medioambiental, colaboración digital, interconexión

\section{Resum}

La literatura infantil contemporània ha desenvolupat un interés creixent en la interconnexió entre els éssers humans i el medi ambient i en els intercanvis i negociacions en curs sobre les maneres que hi ha d'estar al món. Aquestes noves direccions en la literatura infantil, conseqüentment, resulten un repte per al professorat de literatura infantil a l'educació superior. L'estudi de la literatura infantil no només necessita estar al dia sobre les noves perspectives teòriques com l'ecocrítica, el posthumanisme i el nou materialisme, sinó també revisitar, desenvolupar i explorar les eines metodològiques i les pràctiques docents necessàries per preparar l'alumnat per abordar aquestes exigents problemàtiques. El propòsit d'aquest article és presentar i discutir la pregunta de recerca: Com és possible assegurar el diàleg acadèmic i la col-laboració pràctica en un curs escolar de literatura infantil de no-ficció i qüestions mediambientals? A través de la construcció d'un marc teòric interdisciplinari que consistia en teoria de la no-ficció, l'ecocrítica, l'ensenyament dialògic, l'arquitectura mediambiental i l'ensenyament basat en el lloc, l'estudi exposa un curs pilot que va tindre lloc a l'estiu de 2020. Degut a la situació pandèmica, el curs va esdevenir digital. Així doncs, els reptes digitals i les possibilitats van acabar resultant un aspecte crític de la col·laboració pràctica planificada entre estudiants, docents i estudiants i docents. El principal objectiu del curs era ajudar a motivar l'alumnat per engrescar-se i negociar al voltant de la literatura infantil de no-ficció i la sostenibilitat, millorar les seues experiències estètiques i nodrir la seua consciència mediambiental a través de la literatura infantil. El curs es va caracteritzar per l'alternança de classes i experiències pràctiques amb eines teòriques i metodològiques com amb també indrets culturals i naturals específics.

Paraules clau: Literatura infantil de no-ficció, diàleg ecocrític, arquitectura mediambiental, col·laboració digital, interconnexió 


\section{Introduction}

Contemporary children's literature has developed a growing interest in the interconnectedness between humans and the environment and in the ongoing exchange and negotiation of ways to be in the world. These new directions in children's literature consequently challenge teachers of children's literature in higher education. The study of contemporary children's literature needs not only to be informed by new theoretical perspectives like ecocriticism, posthumanism and new materialism, but also to revisit, develop and explore the methodological tools and teaching practices necessary to prepare students to address these demanding issues.

Sharing a common interest in the new environmental direction of contemporary children's literature, we started planning, in August 2019, a pilot course devoted to students, postgraduate teachers, young and senior educators, librarians, cultural operators and experts to take place in a small town on a hillside in Italy. Due to the COVID-19, the course had to move from the environment of Sarmede to the individual environments of the participants and the teachers such as kitchens, regular workplaces, bedrooms or balconies. Initially we regretted and worried about this change from one place to many places. Then, in March 2020, we decided to try to create a digital didactic space as personal and interconnected as possible.

This article discusses and justifies how we designed an academic course on ecocritical dialogues and nonfiction children's literature, guaranteeing at the same time a place awareness in teaching practices although the course had become digital. In order to do so the outline of the article is as follows: First, we present the principal theoretical framework consisting of theory on children's nonfiction, dialogic teaching and ecocritical literature conversations, and environmental architecture. Second, and in line with the theoretical framework, we This article discusses and justifies how we designed an academic course on ecocritical dialogues and nonfiction children's literature, guaranteeing at the same time a place awareness in teaching practices although the course had become digital. present and justify the course design. Third, we present and discuss two examples of students' digital collaboration. Finally, we conclude by indicating the main didactic achievements.

Even if the general ideas offered by ecopedagogy (Gaard, 2009) or ecocritical pedagogy (Garrard, 2012; Bartosch \& Grimm, 2014) were relevant to our project, we found few previous studies that combined environmental aware children's literature with the dialogic teaching of literature in higher education. The studies we are building on are presented and referred to in the theoretical framework. 


\section{The theoretical framework of green dialogues}

Exploring innovative interdisciplinary theoretical and didactical approaches to children's literature in a changing word is one of the major challenges in our research field. Inclusive and reflective societies are becoming more demanding, and teachers are looking for new educational projects that can respond to these needs. Building a theoretical framework capable of melding nonfiction, dialogic teaching, ecocritical literature conversations and environmental architecture goes in that direction.

Initially spread out and dependent on a few especially interested scholars, the academic attention to and theoretical exploration of nonfiction children's literature have become more international, unified and discussed across the field of children's literature research. There may be several reasons for this change, both within the research field and within the market of children's nonfiction. One may point to a growing interest in the many and various forms of knowledge communication and integration in children's literature. One may also cite the tendency to mix and challenge presupposed ideas about the limits between art and science. Consequently, recent theoretical approaches to children's nonfiction have tried to scrutinize and conceptualize these many forms and art-science mixtures. The latest and perhaps potentially most influential scholarly works are a large study of a national (American) corpus (Sanders, 2017), an example-based introductory characterization (von Merveldt, 2018), an aesthetic focus on a nonfiction award (Grilli ed., 2020), and an international volume on nonfiction picturebooks (Goga et. al., 2021).

The concept of nonfiction children's literature refers here to books that select, organize and interpret facts and figures to help readers to become curious or gain knowledge about the world. These books may use both verbal and visual strategies and different narrative and descriptive forms to make knowledge accessible and engage readers intellectually and emotionally. Nonfiction picturebooks have exploded in both quality and quantity in the last ten years. In these books, visual and typographic strategies are as important as the verbal strategies (e.g., Salisbury, 2020; Martins \& Belmiro, 2021).

Curious about the teaching or educational potential of this rich mixture, we wondered if it was possible to organize an active learning (Fedeli \& Bierema, 2019) course that put emphasis on contemporary nonfiction children's literature thematically oriented towards environmental issues. Hence, we carefully selected our analytical as well as explorative examples to centre around books about plants (particularly trees), animals, homes, and houses (linking up with the Greek root of 'eco', that is, 'oikos' meaning 'house'), and biographies (lived life). 
A key tool applied to encounter, explore, and discuss the various literary examples during the course was the ecocritical dialogue or literature conversation (Goga \& Pujol-Valls, 2020). The idea of ecocritical literature conversations builds on the theoretical perspectives of ecocriticism and acknowledged research on dialogic teaching. An often-cited definition of ecocriticism is found in Cheryll Glotfelty's introduction to The Ecocriticism Reader (1996) and reads "ecocriticism is the study of the relationship between literature and the physical environment" (p. xviii, our italics). She further underscores that "ecocriticism takes an earth-centered approach to literary studies" (p. xviii). Building on Glotfelty's definition, Greg Garrard (2004) deepens the definition of ecocriticism as "the study of the relationships between the human and the non-human, throughout cultural history and entailing critical analysis of the term 'human' itself" (p. 5, our italics). In line with and supplementary to these definitions, theorists within posthuman and new materialist thinking (e.g., Barad, 2007; Haraway, 2008; Braidotti, 2019) have challenged what have been considered firm binaries (like nature-culture, humannonhuman) and focused on the entangled and co-shaping networks of the many various life forms and diverse matter. Rosi Braidotti (2019) underscores that the posthuman subject is embodied and embedded in a relational becoming where the identity of the subject is a constant negotiation with human and more-than-human others. Both Donna Haraway and Karen Barad have been occupied with ethical implications of communication, response, and care when diverse life forms and matter intertwine and interact with each other. According to Haraway (2008), the point is simple: "we are in a knot of species coshaping one another in layers of reciprocating complexity all the way down" (p. 42).

This attention towards the relationship, or a relational exchange, between literature, the human, the non-human and the physical environment complies with the key ideas of dialogic teaching. According to Robin Alexander (2020), dialogic teaching builds on the idea that children construct meaning "from verbal interaction with others - parents, teachers, peers - and the worlds those others inhabit" (p. 13), and that carefully prepared and adapted opportunities to talk or participate in dialogues may lay the groundwork for students' examination and negotiation of meaning (p. 36). When an ecocritical perspective is incorporated into the talk, it has the potential to be directed towards the entangled network between literature and the physical environment and to take an earth-centred, or ecocentric, approach to the text. If aiming for an ecocentric talk, a timely key question is how to arrange for dialogic teaching in accordance with ecocritical and ecological insights. As further specified by Alexander, the six main principles guiding the planning and conducting of classroom talk are collective, supportive, reciprocal, deliberative, cumulative and purposeful (p. 131). Hence, ecocritical literature conversations 
should build, to rephrase Rupert Wegerif's 'dialogic space' (2007), ecodialogic spaces for students appropriate to support collective analyses of texts, and deliberative and reciprocal discussions, thinking together, and negotiations of the meaning of a literary work from an ecocritical perspective. Or summed up in the words of Alexander (2020), "[t]alk illuminates text, and text illuminates talk" (p. 90). This, in turn, may be broadened to stating that talk and text illuminate the natural world, and the natural world illuminates talk and text.

The quality of life of human beings not only depends on the relationship with other life forms but it is also tightly entangled with specific settings or localities (Orr, 2002). This awareness could be further cultivated in order to foster a more profound comprehension of ecology and sustainability and to enrich an active ecological imagination. Following David Orr, we should struggle for new ways "to expand the ecological

The quality of life of human beings not only depends on the relationship with other life forms but it is also tightly entangled with specific settings or localities (Orr, 2002). This awareness could be further cultivated in order to foster a more profound comprehension of ecology and sustainability and to enrich an active ecological imagination. imagination of our students, to stretch their sense of possibilities, and to connect them to people changing the world" (p. 159). Linking environmental education, architecture and children's literature is one of these possibilities. Architecture gives shape to various forms of human habitation and embodies a beloved space like a home. In the 20th century innovative architects built houses looking at the needs of a transforming society, including a greater contact between human and nature. Their works also helped forge the image of houses and architecture in children's literature (Campagnaro, 2021). Some designers and architects state that children's picturebooks had a great impact on their imagination as children (Lange, 2018) and even conditioned the way they view architectural spaces as adults (Hong, 2018). Some studies (Ebrahimi et al., 2016) demonstrate how children's literature can, for example, provide architects with ideas and inspiration, by observing "the rules governing the structure of a literary work" (p. 1159). Hence, architecture in children's literature can turn out to be a strategic ally to help students to develop a more respectful attitude toward the environment and to become more conscious of their constructed environment.

Children's literature can expand ecological awareness and imagination because it is capable, for instance, of conceiving buildings as if they were alive, like trees or living organisms (McDonough \& Braungart, 2002). Homes and architecture in children's books are often depicted as innovative ecological landscapes which include fresh air, flowering plants, daylight in many spaces and roofs covered in soil and trees. Fictional cities in picturebooks offer beauty, nature and comfort for 
many inhabitants. These representations are capable of connecting aesthetic literacy, green building literacy (Cole, 2019) and science education, and offer insightful literary examples of how to integrate design and science.

The common features of these theoretical perspectives became the crucial guidelines for the overall and holistic course design and the green dialogues in particular. Summing up, these features may be identified as the entangled, reciprocal interaction between verbal and visual strategies in nonfiction, students, students and texts, as well as environment, living conditions and sustainability for all lifeforms.

\section{Course design}

In line with the established theoretical framework, our course was designed to motivate

[...] ]our course was designed to motivate students to engage in and negotiate about children's nonfiction, to foster their environmental consciousness through participatory and collaborative reading, and to increase their knowledge about how scientific and aesthetic themes in children's literature, like evolution, ecology, and environmental architecture, may be joined in the overarching theme of sustainability students to engage in and negotiate about children's nonfiction, to foster their environmental consciousness through participatory and collaborative reading, and to increase their knowledge about how scientific and aesthetic themes in children's literature, like evolution, ecology, and environmental architecture, may be joined in the overarching theme of sustainability. To be able to give an overview of the main elements of the course design, the following section is organized in five subsections, each presenting and accounting for

one of the key elements of the course: key topics, selection of books, didactic organization, workshops, and laboratories.

\subsection{Key topics}

To both narrow down the broad field of nonfiction children's literature and to provide students with examples relevant to the principal ideas identified by the scholarly works within nonfiction children's literature, ecocriticism, dialogic teaching, and environmental architecture, we decided to concentrate on four key topics: trees, animals, biographies, and homes. The students were asked to sign up for groups according to these topics, that is, we had a tree-group of students, an animal-group, a biography-group, and a home-group. By giving them the opportunity to 
choose a topic, we hoped both to increase their general engagement in the course and to provide them with experiences of participation and reciprocity from the very beginning.

\subsection{Selection of books}

Expertise in the sphere of visual and aesthetic literacy is closely connected to the capacity to read, understand, interpret, and use facts and figures to create knowledge, and to appreciate harmonious forms and innovative modalities of verbal and visual strategies in nonfiction picturebooks (Goga et al., 2021). This is the reason why we paid a great deal of attention to the selection of the nonfiction picturebooks for our course. We selected picturebooks that could provide students with a more articulate and critical relationship between picturebook theory (Kümmerling-Meibauer, 2018), aesthetics and science and at the same time foster their environmental awareness. Therefore, we chose nonfiction picturebooks with very diversified shapes and graphical solutions (see Figs. 1a and 1b).
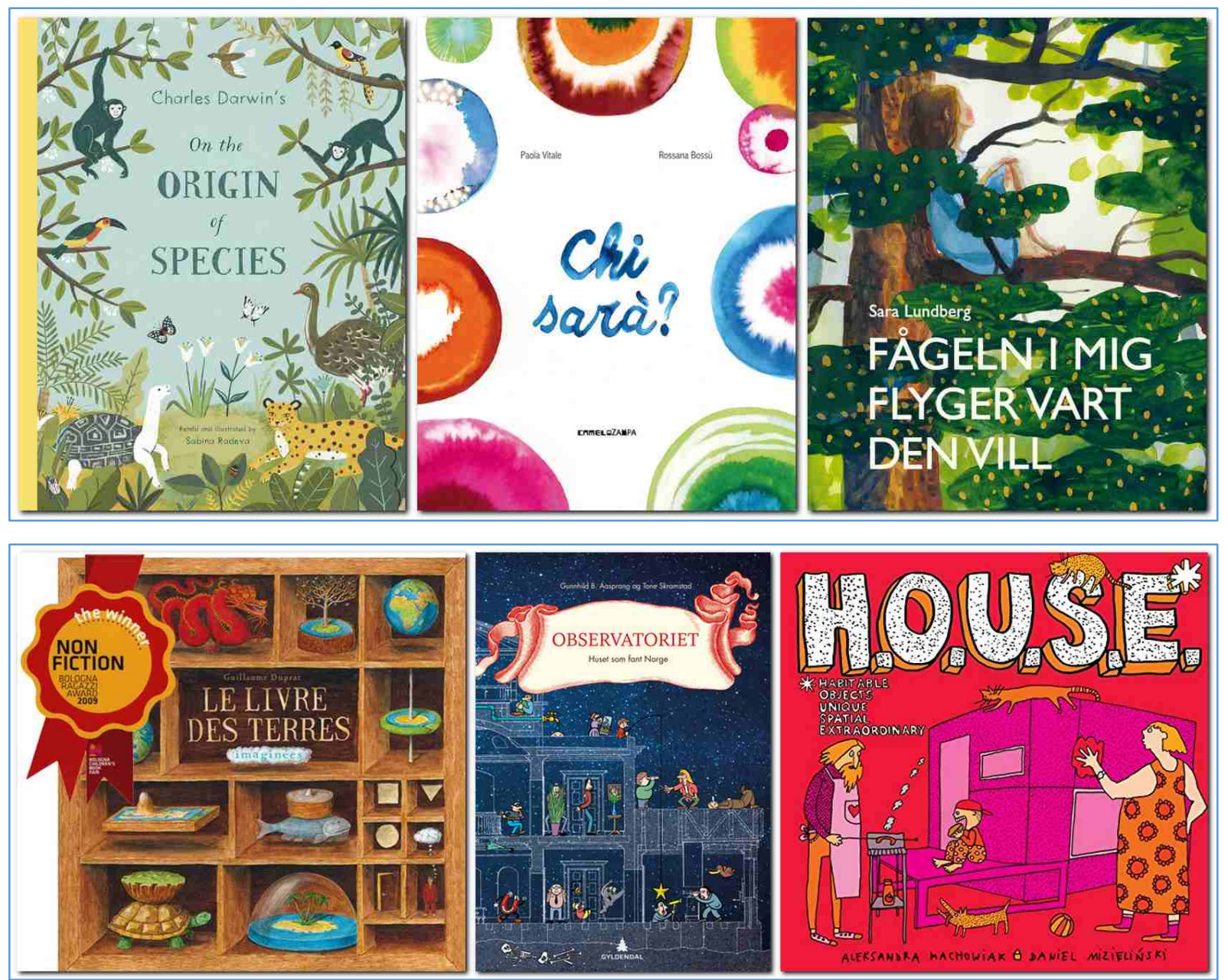

Figures 1a and 1b. Covers of some of the selected picturebooks. 
Our selection was based on three criteria. The first criterion was to select picturebooks which were published very recently and presented interesting qualities such as innovative picture-text relationships, high-quality graphical layout, rich materiality and challenging hybridation. Secondly, we decided on picturebooks which contained complex paratextual elements that could be analysed with students to support their exploration of nonfiction features, such as information accuracy. Thirdly, we chose picturebooks that were able to invite readers to engage in the texts and to examine the various verbal and visual strategies used and combined to impart knowledge and ideas about the world.

\subsection{Didactic organization}

We also paid special attention to the online didactic organization. We used an active learning approach that could offer students the chance to be effectively engaged during the digital lessons with us and with the course material through discussions, problem solving, case studies and peer evaluation. During the course, we varied the time management of our activities. Different strategies were applied during the course such as:

- whole class lessons from 45-60 minutes

- microteaching approaches with sessions around 15-20 minutes, followed by a short activity for students (between 2 and 5 minutes)

- rich didactic schedules: plenary session, workshop, observation activity and discussion, peer review and feedback, reflection, and recap.

- different digital didactic tools: Zoom breakout rooms, Zoom polls and Slido, which is a tool for presentations that turns Q\&A or word cloud sessions into more engaging conversations.

\subsection{Workshops}

To keep a balanced exchange between lectures and participatory activities, we arranged one to two workshop sessions each day. The workshop groups were decided by the choice of topic, that is, we had a tree-group, a home-group and so on. The aim of the workshops was to create an arena where the participants could discuss the ideas presented in the lessons in relation to a 
specific project of their own. During the course of the workshops, the students were supposed

Hence, the students were encouraged to have a negotiative attitude and approach to the utterances and ideas of the others and to be open minded regarding their own ideas, that is, open to broadening their perspective or changing their opinion. to plan, carry out and present this project. The first work in groups was to present a preselected nonfiction book to the group. This helped the group participants to get to know each other better and to start familiarizing themselves with the topic they had signed up for. Additionally, the exchange of book presentations facilitated the work to be done in the next workshop, where they were supposed to start planning what to do and how to do it. Since each workshop session was

summed up in a plenary session including feed-forward comments from peers and teachers on ideas and work in progress, part of the next workshop was to inspect, adjust and decide on their ideas and plans. As a rule, both in plenary discussion and in discussions in breakout rooms the students were encouraged to listen carefully to each other, secure time, and space for everyone to share their ideas (take turns) and to ask clarifying questions if, or when, something was difficult to comprehend or agree upon. Hence, the students were encouraged to have a negotiative attitude and approach to the utterances and ideas of the others and to be open minded regarding their own ideas, that is, open to broadening their perspective or changing their opinion.

\subsection{Laboratories}

To both promote and perhaps include an environmental and to a certain degree also an ecological awareness in the various projects and to emphasize the importance of dialogue, sharing and negotiation, we arranged dialogic laboratories in the form of ecocritical literature conversations. The book selected for this conversation was the picturebook Un grande giorno di niente (2016) by Italian author and illustrator Beatrice Alemagna. The book seemed suitable for discussing a literary work from an ecocritical point of view because it fits the concept of an environmentally oriented work, which, according to Lawrence Buell (1995, pp. 7-8), features a nonhuman environment in a way suggesting that human history is involved in natural history, while the human interest is not understood to be the only legitimate interest. In addition, human accountability to the environment is part of the text's ethical orientation and the environment is a process rather than something constant or given. The plot of Un grande giorno di niente contains many shifts and encounters between the main character and his environment (see Fig. 2). 


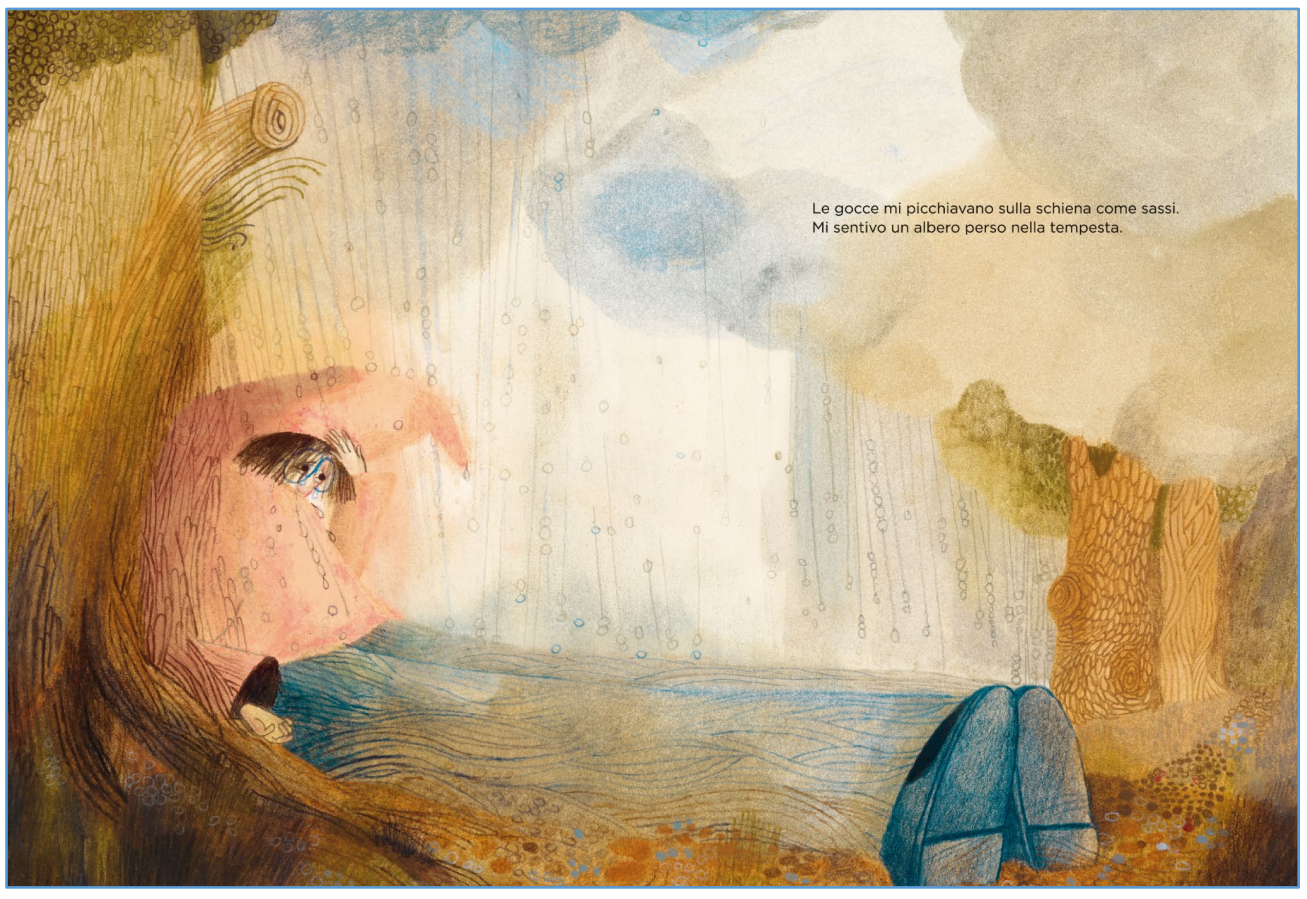

Figure 2. Un grande giorno di niente (2016) by Beatrice Alemagna, Topipittori. Reproduced with permission.

These encounters were open to students' exploration and discussion, but could also be reflected upon in relation to their own connections with nature, which they shared in a place-based lesson at the end of the course (see Fig. 3).

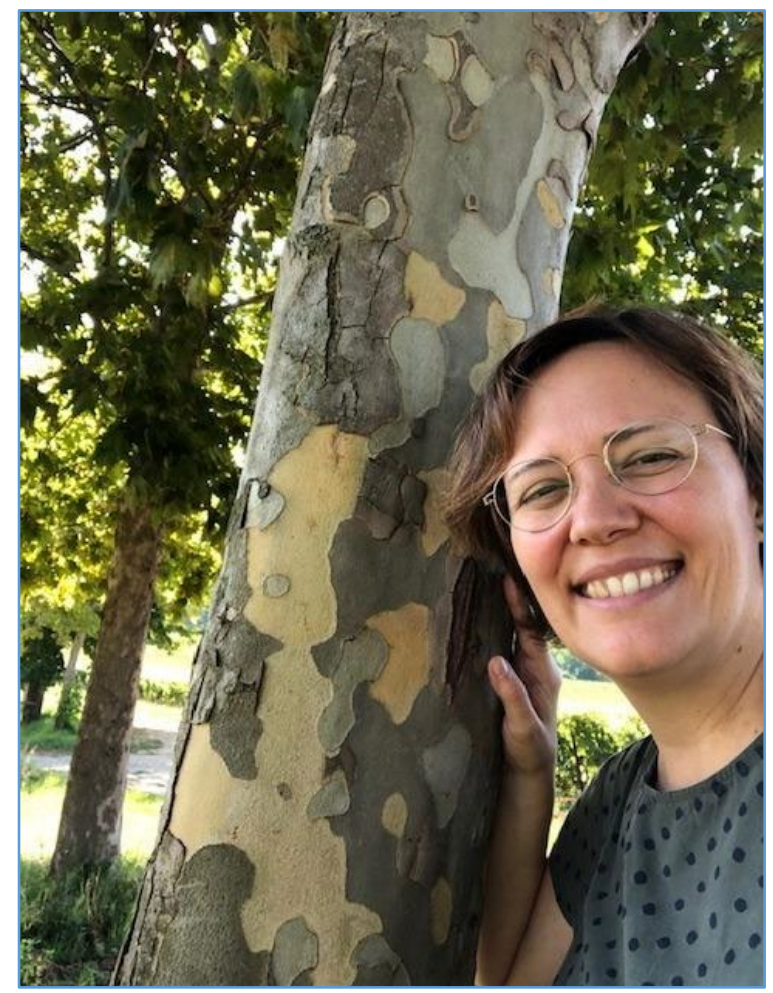

Figure 3 Student and tree. An example of place awareness in a didactic digital environment. Permission was given to share the student photo. 
Using digital sharing tools (like Slido) and plenary talk, students were asked to move through the picturebook, paying special attention to some of these child-nature encounters. The various sharing modes and the teachers' responses modelled ways to revoice, rephrase, request evidence of reasoning and challenge students to test another perspective (Alexander, 2020, p. 111-112). As evidenced in the following two examples, many of these modes were later included in the students' projects.

\section{Output - Two examples of students' digital collaboration}

To be able to present and discuss in more detail how the exchange or transmission between lectures, workshops and dialogue worked during the course, we focus on two of the four topics, trees and homes. These topics are seemingly different, as something organic and slow moving versus something firm and inorganic, but, perhaps not surprisingly, they are more intertwined with each other than one might think at first glance. We should also recall that in children's literature we often see how children build houses or seek refuge or a place of their own in trees. Trees and homes are both some sort of shelter to humans, places to climb, to connect with and be sensitive to environmental stimuli (rain, wind, sun- or daylight). As pointed out by Emanuele Coccia in his book The Life of Plants: A Metaphysics of Mixture (2019, first published in French in 2017), plants, obviously including trees, are "the most intense, radical, and paradigmatic form of being in the world [and to] interrogate plants means to understand what it means to be in the world" (p. 5). Coccia further stresses that plants connect air, or breath, sun and soil, and that they are the centre of where "everything comes into contact with everything else" (p. 27). Finally, and worth mentioning, Coccia sees plants being in the world as a means "to exercise influence especially outside one's own space, outside one's own habitat, outside one's own niche" (p. 43). Hence trees and environmentally intertwined homes may be perceived as places for dialogic, exchange-based, reciprocal relations and collaborations, between students, readers, books and the environment.

\subsection{Trees - creating a double dialogue between storyline and encyclopaedia}

The decision to focus on trees as one of the four subjects was motivated by an interest in cultural plant studies within the field of ecocriticism and in the many representations of trees in children's literature, both the symbolic and metaphoric meaning, but also the geo-cultural significance of trees in children's literature, such as the frequent appearance of birch and pine trees in Norwegian and Swedish children's books (Goga, 2020; Borg \& Ullström, 2017). Hence 
one short lesson addressed the topic of trees in children's literature. Also, in the picturebook selected for the ecocritical literature

The decision to focus on trees as one of the four subjects was motivated by an interest in cultural plant studies within the field of ecocriticism and in the many representations of trees in children's literature, both the symbolic and metaphoric meaning, but also the geo-cultural significance of trees in children's literature, such as the frequent appearance of birch and pine trees in Norwegian and Swedish children's books conversation, the intra-action with trees played a pivotal part. As mentioned above, such intraaction with trees seemed to be picked up and emphasized when the participants, on the last day of the course, were asked to give a place-based presentation of something connecting with their project.

The workshop group concerned with trees first presented their preselected books to each other and then decided on one of the books to present

in the plenary session. The tree-group presented the books Ortica (2020, Nettle - subtitled: A guide to how to listen to wild nature) by Marina Girardi, Dans la forêt (2011, In the forest) by Anouck Boisrobert and Louis Rigaud, Raccontare gli alberi (2013, To tell the trees) by Pia Valentinis and Mauro Evangelista, and finally, Come un albero (2017, Like a tree) by Rossana Bossù. Their choice of books clearly manifested their interest in directing their project in a nature-aware direction. Their collective work was inspired by these books, in particular the picturebook Ortica, as well as by specific nonfiction devices and ecocritical perspectives they picked up in the lectures. That is, they decided to make a leporello, a two-sided book, titled Tree street number 4, with a storyline, a walk on one side and an encyclopaedic and educational part (questions, activities, challenges) on the other side (Figs. 4a and 4b).

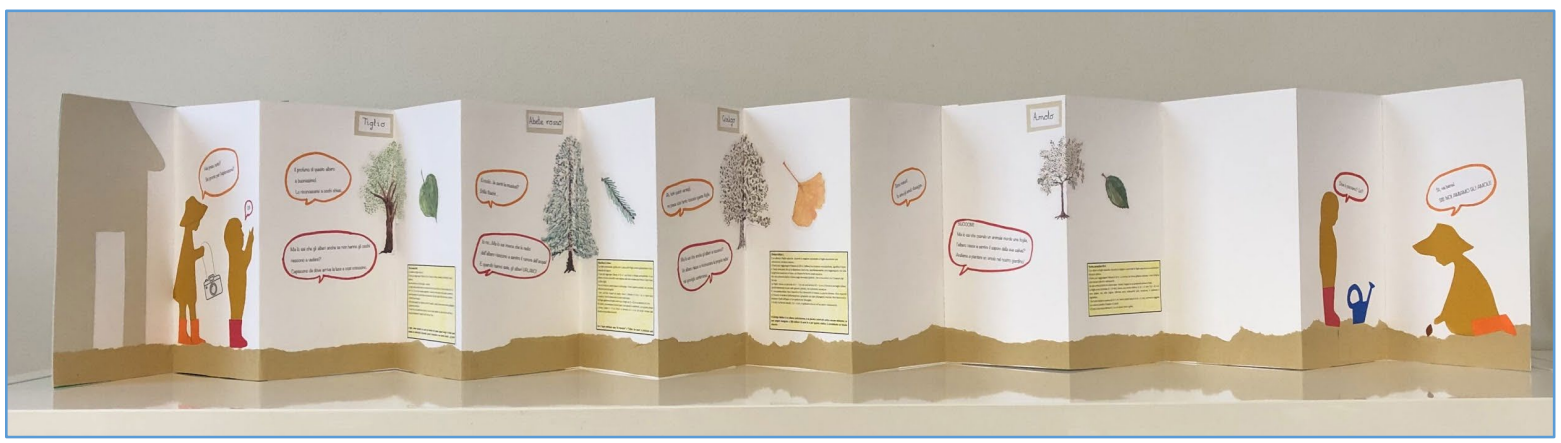

Figures 4a. Project work on trees. Permission was given to share the students' work. 


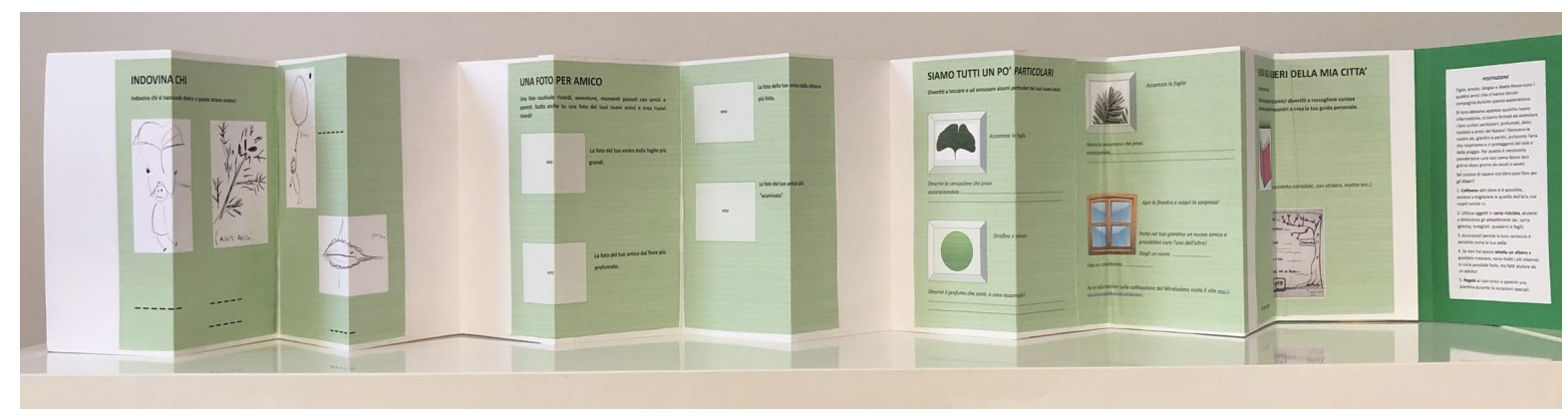

Figures 4b. Project work on trees. Permission was given to share the students' work.

One may suggest that the choice of format was based on the principal ideas of dialogic teaching and thinking. To be able to turn and fold is a physical manifestation of the sharing of turns and unfolding of thoughts characteristic of a true dialogue.

- The walk was taken by two child characters, where the smaller one seemed to be the one with the answers and the bigger one the one with the questions. As one may observe in the students' work, the aim of the two children's walk was to plant a tree.

- The educational side of the leporello encouraged readers to learn the names of leaves and to take a photo of a friend - indicating that trees are our living fellows and friends. It also enticed readers to touch and smell leaves, seeds, and tree bark and to make their own neighbourhood walk of trees.

The final result confirms that the students managed to apply the theoretical knowledge to their own work and that the collaborative sharing of ideas and suggestions was crucial to the richness of their material work.

\subsection{Homes - creating a poetic and scientific interplay between light and leaves}

As stated, be it real or imaginary, and even when it is not manifested (Reimer, 2013), home is an essential topos in children's literature. It is so relevant because it is the place where protagonists live, struggle to grow or which they decide to leave behind when they move away for adventure. Moreover, a home is also significant in children's literature because it can be considered either as a space of psychological characterization or as a symbol of cultural and socio-historical evolution (Campagnaro, 2019). We decided to include it in our didactic programme because differently from many studies of the representation of homes in fiction picturebooks, very little research and teaching have been conducted on homes in nonfiction. Finally, recent research emphasizes that introducing green building practices in education can significantly contribute, 
for instance, to the development of ecological literacy in primary classrooms (Zangori \& Cole, 2019). Our aim was to connect all these features in a didactic workshop that was able to convey a positive human-ecosystem impact relationship and stimulate a growing awareness of humanecosystem connections. These are the main reasons why we selected home as a topic for our laboratory.

For students to focus on abiotic and biotic relationships in nonfiction picturebooks was a quite demanding task because they were also invited to reflect on how architecture is able to respond to social problems and give effective answers to future challenges, like for instance promoting cultural diversity and developing environmental sustainability.

The group devoted to houses presented their preselected books to each other and then in the plenary session. Only one member, however, discussed a picturebook about homes and architecture. The picturebook was Case nel mondo (2018, Homes in the world) by Mariapaola Pesce and Martina Tonella. Other members preferred to show nonfiction picturebooks they were particularly fond of, especially picturebooks about animals, which is a rich typology in the market of nonfiction.

The fact that they presented books other than books on homes created some difficulties when the house-group started exploring and sharing ideas about homes for their project in the laboratory. That is, they lacked guiding examples for their work. In fact, these students worked hard but they struggled to find a harmonious consensus within the group. As an outcome, they decided to create an elegant photo-illustrated nonfiction picturebook about the characteristics and the perception of light in a familiar place such as a home.

The aim of their project was to study the phenomenon and the properties of light from the scientific point of view. Therefore, they investigated natural and artificial light in a familiar space such as the home (Figs. 5a and 5b). They introduced many different topics (the relation between the natural light and the perception of colours or between the natural light and geographical positions, time, and hours of the day, and so on). They also used scientific words like electromagnetic waves, electric fields, visual spectra, refraction, quantum leaps, and so on. 

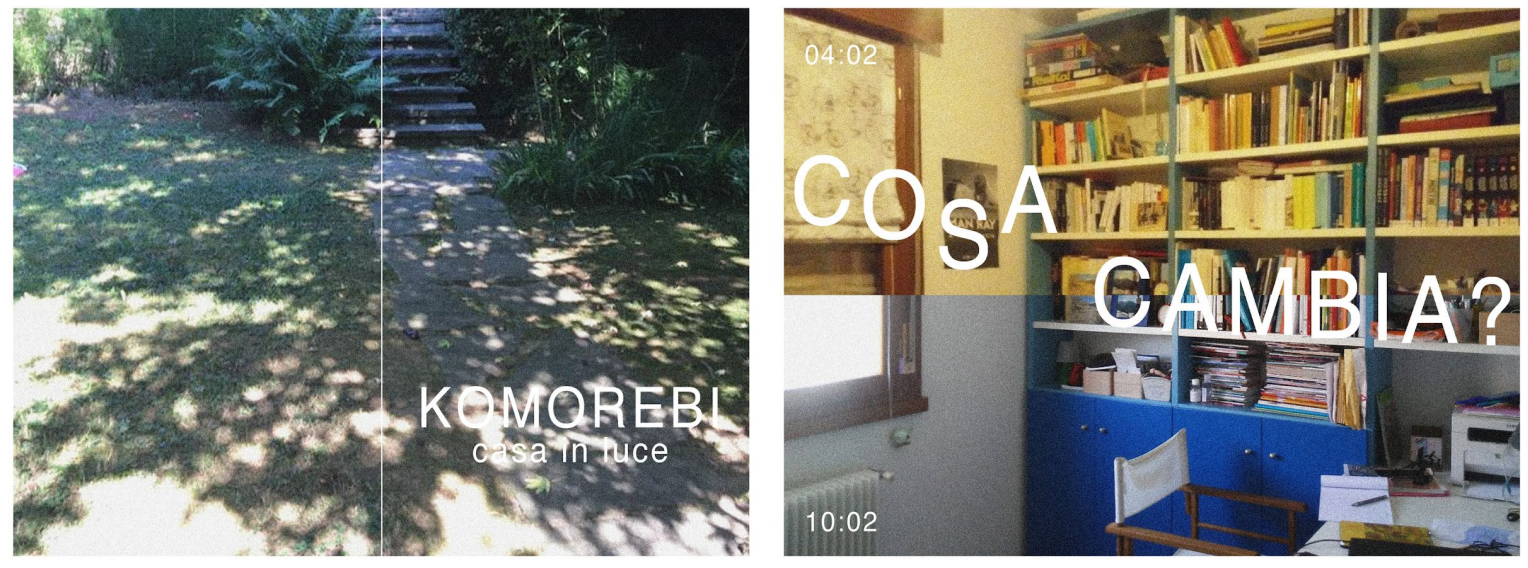

Figures $\mathbf{5 a}$ and $\mathbf{5 b}$. Project work on homes. Permission was given to share the students' work.

Another interesting aspect of their project was the title they chose for their book. They named it Komorebi. Lighting home. In the Japanese language, "komorebi" is a word to indicate the fascinating interplay between light and leaves when sunlight shines through trees. The shadows cast on the ground or even through the curtains create an everyday and peaceful beauty. So the presence of trees and natural sunlight reflects their sensitivity to the connection between homes and nature. From this perspective, they managed to develop an intriguing approach to humanecosystem connections.

Even though they had many inspiring ideas, topics, and activities in their picturebook, which was really well designed, they fell short in their main task. Probably the difficulty was linked to the fact that they didn't find a positive balance among all the members of the group. This aspect caused problems in accomplishing the goal of their project, which was to help young readers to observe and develop a silent, contemplative and ecocritical attitude towards the viewing of sunlight through trees inside a house.

\section{Didactic achievements - A sort of conclusion}

To conclude, we suggest that, all in all, the digital laboratory course "in Sarmede" proved that the students managed to engage aesthetically with children's nonfiction, that their encounters with a variety of picturebooks with a special emphasis on the selected topics and their reflections and workshop discussions had the potential to promote environmental consciousness, and that although the course was digital, we were able to build an interconnected community, including emotional engagements. 
The students' aesthetic engagement with picturebooks is evidenced in their group presentation of preselected books, in the ecocritical literature conversations, as well as in their own project work, which applied several aesthetic elements. The fact that the students included environmental and ecological oriented layouts, questions and tasks in their project work indicates that the picturebooks examined (in the whole class and in groups) and the pre-decided topics of the course were a helpful framework for most of them. Originally planned to be a substantial place-based course including open-air lessons, tree climbing, building excursions, soil and weather sensations, and walks and talks, the didactic digital environment had to be built in a way that allowed students and teachers to connect with each other and with each other's places. Not only was the outdoor lesson in Zoom, where students and teachers invited the others to take part in their local environment and their topic related site, of great [...] the digital laboratory course "in Sarmede" proved that the students managed to engage aesthetically with children's nonfiction, that their encounters with a variety of picturebooks with a special emphasis on the selected topics and their reflections and workshop discussions had the potential to promote environmental consciousness, and that although the course was digital, we were able to build an interconnected community, including emotional engagements importance in building an interconnected and environmentally aware digital community. The balanced use of plenary sessions, written and oral exercises and breakout room sessions - where teachers came to listen and take part in the discussion - also proved to be absolutely essential.

According to the students reports and feedback, they also experienced these achievements: "Very good the richness of both the picturebooks that were analysed and the hands-on activities (Slido, plenary sessions, individual work, group-work, feedback). [...] Even if we could not look into each other's eyes, there was, however, a welcoming common attitude to listen and share". The students' feedback also contained some critical elements, mostly related to the length of the sessions and the lack of the possibility to sense the materiality of the picturebooks. Based on their feedback and our own experiences with several challenges, we hope to have the opportunity to fulfil these requests and improve the course in the near future. 


\section{References}

Alexander, R. (2020). A dialogic teaching companion. Routledge.

Barad, K. (2007). Meeting the universe halfway: Quantum physics and the entanglement of matter and meaning. Duke University Press.

Bartosch, R., \& Grimm, S. (Eds.) (2014). Teaching Environments. Ecocritical Encounters. Peter Lang Edition.

Borg, C. B., \& Ullström, M. (2017). The child in the forest. Performing the child in 20th century Swedish picture books. LIR.journal, 9, 7-24.

Braidotti, R. (2019). Posthuman knowledge. Polity.

Buell, L. (1995). The environmental imagination: Thoreau, nature writing, and the formation of American culture. Belknap Press of Harvard University Press.

Campagnaro, M. (2019). "Narrating” homes and objects: Images of domestic life in Italian picturebooks since the mid-20th century. RPD Ricerche di Pedagogia e Didattica-Journal of Theories and Research in Education, 14(2), 9-48. https://doi.org/10.6092/issn.1970-2221/10030

Campagnaro, M. (2021). Stepping into the world of houses. Children's picturebooks on architecture. In N. Goga, S. H. Iversen \& A.-S. Teigland (Eds.), Verbal and visual strategies in nonfiction picturebooks. Universitetsforlaget. https://doi.org/10.18261/9788215042459-2021-15

Coccia, E. (2019). The life of plants. A metaphysics of mixture. Polity Press.

Cole, L. B. (2019). Green building literacy: A framework for advancing green building education. IJ STEM Ed, 6(18). https://doi.org/10.1186/s40594-019-0171-6

Ebrahimi, S., Akbari, A., \& Haghjou, A. (2016). Evaluating idea-finding ways in architecture to create a childish tone and structure in the design of spaces for children with particular reference to children's literature. Journal of Engineering and Applied Sciences, 11(6), 1155-1162. https://doi.org/10.36478/jeasci.2016.1155.1162

Fedeli, M., \& Bierema, L. L. (Eds.). (2019). Connecting adult learning and knowledge management. Strategies for learning and change in higher education and organizations. Springer International Publishing.

Gaard, G. (2009). Children's environmental literature: From ecocriticism to ecopedagogy. Neohelicon, $36,321-334$.

Garrard, G. (2004). Ecocriticism. Routledge.

Garrard, G. (2012). Introduction. In I G. Garrard (Ed.), Teaching Ecocriticism and Green Cultural Studies (p. 1-10). Palgrave Macmillan.

Glotfelty, C. (1996). Introduction. In C. Glotfelty \& H. Fromm (Eds.). The ecocriticism reader: Landmarks in literary ecology (pp. xv-xxxvii). The University of Georgia Press.

Goga, N. (2020). Økokritiske perspektiv på representasjoner av skog i skandinavisk barnelitteratur. Svensklärarföreningens Årsskrift 2019, 113-129.

Goga, N., Iversen S. H. \& Teigland, A.-S. (2021). Verbal and visual strategies in nonfiction picturebooks. Universitetsforlaget. https://doi.org/10.18261/9788215042459-2021

Goga, N., \& Pujol-Valls, M. (2020). Ecocritical engagement with picturebook through literature conversations about Beatrice Alemagne's On a magical do-nothing day. Sustainability, 12(18). https://doi.org/10.3390/su12187653

Grilli, G. (Ed.) (2020). Non-fiction picturebooks. Sharing knowledge as an aesthetic experience. Edizioni ETS. 
Haraway, D. (2008). When species meet. University of Minnesota Press.

Hong, C. (2018). The children's books that inspired designers. Architectural Digest. https://www.architecturaldigest.com/story/the-childrens-books-that-inspired-designers

Kümmerling-Meibauer, B. (Ed.) (2018). The Routledge companion to picturebooks. Routledge.

Lange, A. (2018). The design of childhood. How the material world shapes independent kids. Bloomsbury Publishing.

Martins, M. \& Belmiro, C. A. (2021). Stylistic strategies in children's nonfiction books. In N. Goga, S. H. Iversen \& A.-S. Teigland (Eds.), Verbal and visual strategies in nonfiction picturebooks (pp. 8-21). Universitetsforlaget. https://doi.org/10.18261/9788215042459-2021-02

McDonough, W. \& Braungart, M. (2002). Buildings like trees, Cities like forest. https://mcdonough.com/writings/buildings-like-trees-cities-like-forests/

Merveldt, N. von (2018). Informational picturebooks. In B. Kümmerling-Meibauer (Ed.), The Routledge companion to picturebooks (pp. 231-245). Routledge.

Orr, D. W. (2002). The nature of design. Ecology, culture, and human intention. Oxford University Press.

Reimer, M. (2013). "No place like home": The facts and figures of homelessness in contemporary texts for young people. Barnelitterært forskningstidsskrift, 4(1). https://doi.org/10.3402/blft.v4i0.20605

Salisbury, M. (2020). True stories and big books: New creative opportunities in non-fiction picturebooks. In G. Grilli (Ed.) Non-fiction picturebooks. Sharing knowledge as an aesthetic experience (pp. 91-107). Edizioni ETS.

Sanders, J. S. (2017). A literature of questions. Nonfiction for the critical child. University of Minnesota Press.

Wegerif, R. (2007). Dialogic education and technology: Expanding the space of learning. Springer.

Zangori, L., \& Cole, L. (2019). Assessing the contributions of green building practices to ecological literacy in the elementary classroom: An exploratory study. Environmental Education Research, 25(11), 1674-1696. https://doi.org/10.1080/13504622.2019.1662372

How to cite this paper:

Campagnaro, M., \& Goga, N. (2021). Green Dialogues and Digital Collaboration on Nonfiction Children's Literature. Journal of Literary Education, (4), 96-114. https://doi.org/10.7203/JLE.4.21019 